\title{
Social representations of students in the construction of the professional identity of nurses
}

\author{
Representações sociais de estudantes na construção da identidade profissional do \\ enfermeiro
}

Rayanne Branco dos Santos Lima ${ }^{1}$, Maria Socorro de Araújo Dias², Maria da Conceição Coelho Brito ${ }^{3}$, Alexandro do Vale Silva ${ }^{2}$, Lucilane Maria Sales da Silva ${ }^{3}$, Janaína Fonseca Víctor Coutinho ${ }^{1}$

\begin{abstract}
Objective: to analyze the social representations of students in the construction of the professional identity of nurses. Methods: qualitative study with 60 students from the Nursing course of a public university. Collection was done through instruments of aesthetic production scenes. The results were analyzed based on the Theory of Social Representations. Results: a total of 190 objectified images emerged, of which 29 expressed charity, 38 were related to technicality, and 22 presented different scenarios of performance of nurses. These images constituted three scenes of aesthetic production. Students of the first and fifth semesters brought representations with a greater focus on charity and technicality, and those of the tenth semester presented images related to areas of professional activity. Conclusion: the social representations of Nursing students change with the advance of the academic course, starting with representations from society (charitable and technocratic) and being firmly established in the professional work of nurses.
\end{abstract}

Descriptors: Nursing; Education, Higher; Nurse's Role; Social Desirability; Education, Nursing.

Objetivo: analisar as representações sociais de discentes na construção da identidade profissional do enfermeiro. Métodos: estudo qualitativo, com 60 discentes do curso de Enfermagem de uma universidade pública. Coleta mediante instrumentos de cenas de produção estética. Análise dos resultados embasada na Teoria das Representações Sociais. Resultados: emergiram 190 imagens objetivadas. Foram expostas 29 imagens que expressaram caridade, 38 relacionavam-se ao tecnicismo e 22 apresentaram diferentes cenários de atuação do enfermeiro. Essas imagens constituíram três cenas de produção estética. Os discentes do primeiro e quinto semestres trouxeram as representações com maior enfoque na caridade e no tecnicismo, e os do décimo, apresentaram imagens referentes às áreas de atuação profissional. Conclusão: as representações sociais de estudantes de Enfermagem se modificam com o avançar da academia, iniciando-se com representações advindas da sociedade (caritativo e tecnocismo) e firmando-se no fazer profissional do enfermeiro.

Descritores: Enfermagem; Educação Superior; Papel do Profissional de Enfermagem; Desejabilidade Social; Educação em Enfermagem.

\footnotetext{
${ }^{1}$ Universidade Federal do Ceará. Fortaleza, CE, Brazil.

${ }^{2}$ Universidade Estadual Vale do Acaraú. Sobral, CE, Brazil.

${ }^{3}$ Universidade Estadual do Ceará. Fortaleza, CE, Brazil.
} 


\section{Introduction}

The identity of the human being is continuously formed and transformed, gaining a dynamic character. Thus, personal identity is built in the relationship of man with himself, with others and with the society in which he is inserted ${ }^{(1)}$.

Starting from this premise, the professional builds his own identity through knowledge and individual history. For health professionals, this construction occurs mainly when the worker is in contact with peers and when he provides health care for people, groups and society ${ }^{(2)}$. In this sense, each category has its own professional identity.

In this study, the focus was on the professional identity of nurses, which has a dynamic character, being formed from the first contacts with teachers and professionals of the area, as well as from the interaction with other agents. These experiences are agglutinated and form a conception of what is to be a nurse, favoring the refinement of the identity of each individual $^{(3)}$.

The process of constructing the identity of nurses takes place through social representations that are weighed in the course of training. This is based on the understanding that the human being carries the capacity to attribute symbols to share meanings with peers, recreating his own meanings as he builds his uniqueness. Thus, the construction of identity is understood as an unfinished, multifaceted and hybrid process, subject to reformulations and socio-historical manipulations ${ }^{(4)}$.

Since the 1990s, in Brazil, Nursing has been building knowledge with theoretical and methodological support of social representations, exploring objects related to health and care of self and of others, in various fields of practice and contexts of action. This is because there is an important identity between nurses' researches and the Theory of Social Representations, because this principle does not hierarchize the types of knowledge of science, common sense, beliefs and myths, and respects the diversities and functionalities, seeking to understand their interbreeding in the formation of representations and practices, crucial for understanding health care ${ }^{(5)}$.

The application of the Theory of Social Representations in nursing research offers an opportunity to understand the interpretations built on care, allowing to know the meanings attributed to it, the material reality that serves as a reference (for establishing anchorages), the explanations engendered to understand people's behaviors, attitudes and choices along the paths they follow in their everyday lives ${ }^{(5)}$. Thus, studying the professional identity based on this reference, considering the itineraries of the academic training and the transitions that occur during this stage, brings the possibility of understanding the educational processes experienced in the development of professional identity.

It is essential to take into account that the university goes beyond the role of promoting expertise in techniques and procedures. In this context, to identify, in the opinion of the students, the transitions that occur during undergraduate training in Nursing is valuable because the students' expectations, experiences and professional image are fruits of the events they live before and during the academic training, with repercussions on the vision of the professional future they will have as nurses. Thus, the question raised was: does the social imaginary have repercussions on what nursing and being a nurse represents for students? Which nursing identities can be recognized in the training process of nursing students?

Thus, this study aimed to analyze the social representations of students in the construction of the professional identity of nurses.

\section{Methods}

Qualitative study carried out in a Undergraduate Nursing course at a university in the countryside of Ceará, Brazil. In order to gather the study sample, the 
participants were selected according to the following inclusion criterion: students who were attending the first, fifth and tenth semesters during the data collection period. The total number of students in the three semesters corresponded to 100 , but 40 students declined the invitation to participate. Sixty students participated in the study, 16 of the first semester, 25 of the fifth, and 19 of the tenth.

Data collection took place, from January to March 2016, by means of two aesthetic production instruments ${ }^{(6)}$ that present a fun aspect as facilitator of the apprehension of representations aimed at stimulating the subjectivity in the participants. Thus, one of the instruments was used to identify the pictographic expressions (expression of ideas through figurative or symbolic scenes), corresponding to a total of 190 productions because each student built more than one production. The other instrument was the verbal expressions of the participants, served to know the social representations of the students about nursing, and also to understand how these representations influence the construction of professional identity. This step was recorded with the prior authorization of the participants.

The information was transcribed verbatim and analyzed under the Theory of Social Representations. This theory proposes principles of objectification (figuration) and anchorage (signification) as structuring to capture the professional identity of the participants as a psychosocial object. In this study, objectification was performed by asking the participants to express images through pictography that would correspond to nursing and to the way nurses are viewed. The productions were grouped and categorized as to the type of image expressed, consisting in scenes. When anchored, these scenes resulted in representations of nursing identity linked to a charitable character, in the biomedical model and in the area of action.

By instigating the students to materialize images that refer to nursing, from the understanding that the objectification aims to transform something that is at abstract or unknown into another nature, something more accessible, making it more concrete and objective. Anchorage helps to associate what is strange to the group to some existing social representation, classifying and naming the unknown ${ }^{(7)}$.

The study was approved by the Research Ethics Committee according to Opinion no 1,323,463/2015 and CAAE no 46346215.9.0000.5053. An Informed Consent Form was signed by the participants who agreed to contribute to this study. In order to maintain the anonymity of the participants, they were identified according to the order of transcription of the information of the learner (L) and according to the semester (S) in which they belonged (L1; S1, for example).

\section{Results}

A total of 190 images emerged from the 60 participants, since each one brought up more than one objectification and attributed different anchorages to them: 29 students presented images that made reference to the charitable character; 38 reported biomedical-related productions by means of medications, syringes, stretchers and bedridden patients; and 22 presented nurses providing care in different areas of action such as the Family Health Strategy, the Mobile Emergency Care Service and Hospitals. The summary of the objectified images, with the respective anchorages, generated the categories expressed in Figure 1.

In order to analyze the 190 pictographic expressions per semester, it was verified that 10 students of the first semester, 23 of the fifth and 10 of the tenth presented images referring to charitable care. Of the images related to the biomedical model, 40 were of students of the first semester, 39 of the fifth and 19 of the tenth. As for images based on areas of action of nurses, they were from eight students of the first semester, 11 of the fifth and 30 of the tenth. 


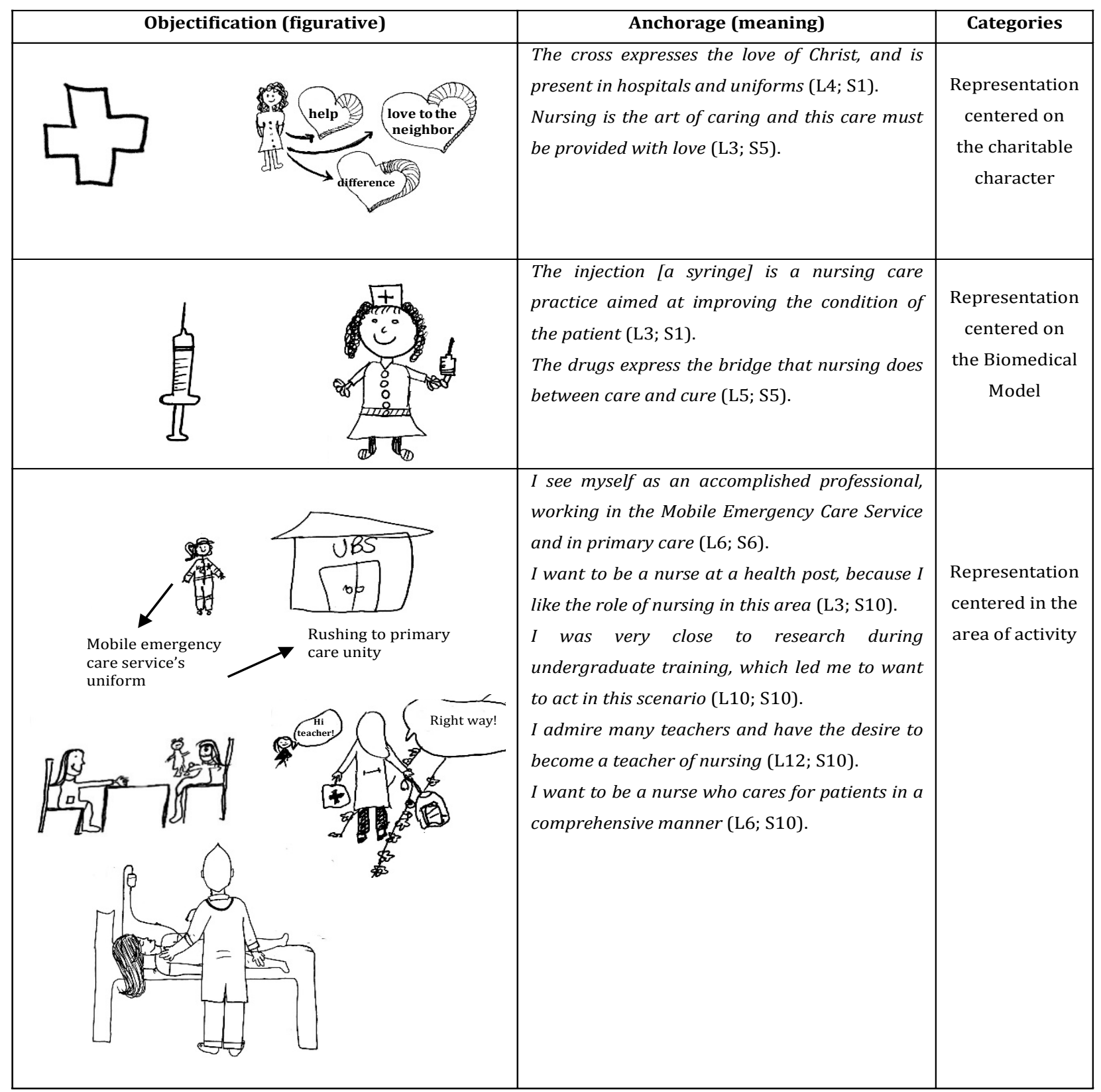

Figure 1 - Objectified scenes and expressions of signification of the students about what nursing represents to them

With the intention of investigating the identity of nurses built on the training itinerary, the students were also asked about the perception of the work of nurses according to the practical experiences of the course. The question was directed to the participants of the fifth and tenth semesters, because students of the first semester had not yet immersed in the fields of practice: I used to think that nurses worked only in hospitals and health posts; I had no idea of the areas of practice (L6; S5). I used to see nurses only as caregivers, but today I see myself as a leader who needs to be able to develop managerial roles (L8; S10). I found out that I can work in companies and educational institutions (L14; S5).

The participants were also asked about the image they had of a nurse as a professional. The representations of the imaginary of the students were: Very important professionals. I used to see them before as technical 
professionals and today I see them as more humanistic professionals. However, they are undervalued (D9; S1). A tired professional, who pours himself into his profession and little valued (L2; S5). I see him as a warrior (L11; S10).

\section{Discussion}

The limitations of this study refer to the understanding of which moments of the undergraduate training favor changes in the social representations of the students and what happens for that to take place, since what was analyzed had occurred in a specific situation. Furthermore, it was not possible to explore the role of training institutions in the construction of the identity of nurses. However, it is necessary to stimulate discussions and establish strategies for future nurses to recognize the importance of their role in society and the value of the science they construct.

Understanding what nursing represents for the students of the study prompts the need to understand the field of human resources in health and, above all, from the perspective of nursing, both in the context of training and professional practice. It is a valuable object of study to problematize the knowledge, powers and subjective practices of health professionals. In this direction, the components of efficiency and effectiveness can historically be reflected from perspectives that allow the understanding and, in particular, the questioning of truths legitimized throughout the history of the profession. In this sense, it is particularly important to consider the role of education, either in the undergraduate or in permanent education, as a propulsive spring for the constitution of the expected traits in the performance and social representation of the nursing professional ${ }^{(8)}$.

In this context, inquiring students who are at certain points of undergraduate training has the goal to understand the images constructed of the profession that come from social ideas, and how they transit and are transformed along the Course. It is evident that, in the first semester, the students present diverse expectations about the course and the profession, often coming from the social imaginary. In the fifth semester, bachelor students intensify their experiences in practical scenarios, with a focus on nursing praxis. And, in the last semester (tenth), the students approach the rite of passage from training to professionalization.

It was verified that the charitable character of care, so historically inherent to nursing, was expressively highlighted in the aesthetic production scenes of the students of the $5^{\text {th }}$ semester. This characteristic may be influenced by the social image of nursing, still considered submissive, auxiliary to other professional categories, and that remains still very vivid in the minds of those who go through the course and have not yet immersed with intensity in a process of appropriation of the know-how of nursing.

When people think about nursing, love, care, self-denial to benefit neighbors, which are all nuances of the creation of the profession, stood out in the speeches of the students. However, when the professional nurse was objectified, he appeared as someone who works hard, a "warrior", and someone who has space in different scenarios of performance, conveying a more current representation of this professional, strongly present in the scenes of the students of the tenth semester.

However, there is a strengthening of the myth of vocational donation by nurses as an alternative to guarantee some social prestige ${ }^{(8)}$. This shows that in the imaginary of these nurses, love and care are characteristics that cause the profession to be remembered by society and receive from it some acknowledgement for the work performed ${ }^{(6)}$.

The above is directly related to the historical trajectory of nursing, which has a religious nature of submission and charity. With the beginning of Christianity, executors who could relate to the nursing work were churchgoers or laymen who had developed a spirit of charity ${ }^{(9)}$. This period imprinted deep marks in the history of humanity and they are imprinted in our values, in our daily behaviors, until the present days. These marks still persist and are explicit in the 
nursing conception of students and nurses.

The presence of crosses in the images produced by the students leads us to infer that this has a close relation with the media stereotypes of nursing, with white clothes and a hat with the sign of the red cross. The presence of the cross in the uniforms used by the nurses for several years originated with the Red Cross institution, whose founder was Swiss Jean Henri Dunant (1828-1910) ${ }^{(10)}$. This symbol has the meaning of inviolability and respect toward people and institutions destined to the assistance, mainly, during war.

The Brazilian Red Cross was founded in Rio de Janeiro and contributed to the professionalization of nursing in Brazil, with the creation of the Practical Nursing School in 1916 ${ }^{(11)}$, an institution under the leadership of Dr Getúlio dos Santos (1881-1928 $)^{(12)}$.

The training of nurses by physicians was common. However, the hegemonic biomedical model around the world for the actions of Medicine and related areas began to be the target of criticism by the $1970 s^{(13)}$. It is still a model that exerts a strong influence on the social imaginary, evidenced by the expressive number of scenes related to this model in this study.

As a stimulus to the social and academic movements that propelled the Sanitary Movement, a discussion on the vision focused on diseases was not enough to solve the processes of sickness and health that afflicted society. Several events marked the world and were the drivers of a new concept of health in public policies in Brazil. We can mention the Movement for Health Promotion in Canada in 1974, when the first events that resulted in the main official documents on the subject took place ${ }^{(13)}$.

These documents include the Lalonde Report that brought innovations to the health field, broadening the debate on the social determinants of health, triggering a strong preventive regulatory content of daily, life, individualizing the questions about the health-disease process, to the extent in which the lifestyle was placed in the focus of the debate, neglecting the political, economic and social context. As a result, the report fell short the idea of health production or a more emancipatory thought ${ }^{(14)}$.

These movements in Brazil intended to understand Health Promotion as a constitutional commitment of the Unified Health System. The National Policy on Health Promotion was created with this goal, with a view to articulating Health Promotion with the principles and guidelines that guide the Brazilian Health System. This policy is based on strategies and forms of health production, both individual and collective, considering intra and intersectoral articulation and cooperation within the Health Care Network ${ }^{(15)}$.

The implementation of this new perspective in health care requires the participation of Higher Education institutions, as well as of other segments regarding the training of health professionals qualified to meet to the ideal of the Unified Health System. Since the I National Conference on Human Resources in Health, the training of professionals for the Unified Health System is present in the guidelines at the national level, thus mobilizing programs and projects aimed at training/qualifiying human resources $^{(16)}$.

In this scenario, the National Program of Reorientation of Vocational Training in Health (Pró-Saúde) was created with the purpose of encouraging the transformation of the training process, the generation of knowledge and the provision of services to the population based on an integral approach to the health-disease process in a real scenario of practices that is the Network of the Unified Health System ${ }^{(17) .}$

The historical facts presented serve to understand the images represented as a broadening of the working scenarios of nurses, aspects more evidenced in the tenth semester, signaling the possible (re)construction of the image that students have of nurses during the course, based on the experiences lived in the scope teaching, research and outreach activities. This explains each identity expressed by students of each semester and denotes the dynamism and reactional character that permeate the professional identity in the formative process, but not only in it.

An important representation that emerged in the speeches of the students was the nurses as lea- 
ders. Universities have a relevant role in the training of nursing leaders, aware of their rights and duties, skilled not only to learn to do, but to be reflexive, critical, and capable of modifying reality. The mismatch between the training process and the nursing practice results in tensions, demotivation and conflicts.

One of the speeches of the students that brought the image of a nurse as someone tired, with multiple tasks and little valued. This is associated with the multiple precarious links to which nurses are subject. The accumulation of links can have a double characteristic: it can be a cause of pleasure, insofar as it gives a better financial contribution and, consequently, generates a better quality of life; or it can cause fatigue at work and attrition, in the face of excessive hours and difficulties in reconciling social and family life ${ }^{(18)}$.

The attitude of first-semester students in recognizing nurses as undervalued professionals stems from positions that are part of the imaginary of society in general. This may reflect negatively on both the social recognition and the professional identity of nurses ${ }^{(1)}$. Strategies to strengthen social recognition should be enhanced in undergraduate courses, understanding that talking about health education as a strategy for consolidating the Unified Health System implies reflecting on the curricular guidelines as a conceptual, philosophical and methodological basis that directs a new pedagogical proposal in the process of building a professional profile. These should be endowed with skills and abilities that are appropriate to national and international references for the preparation of critical-reflective professionals, transforming social reality, agents of change committed to the health of the population.

\section{Conclusion}

The social representations of nursing students change with the progress of the academic training, starting with representations produced by society (charity and technicality) and getting firmly established in the professional work of nurses. These fin- dings indicate the importance of training to build the professional identity of nurses.

\section{Acknowledgements}

Lima RBS and Brito MCC respectively thank the Fundação Cearense de Apoio ao Desenvolvimento Científico e Tecnológico and the Coordenação de Aperfeiçoamento de Pessoal de Nível Superior for the postgraduate scholarships granted.

\section{Collaborations}

Lima RBS, Dias MSA and Brito MCC contributed in the design of the project, collection, analysis and interpretation of data, and writing of the article. Silva AV, Silva LMS and Coutinho JFV collaborated with the writing and critical analysis of the content and final approval of the version to be published.

\section{References}

1. Beck CLC, Prestes FC, Silva RM, Tavares JP, Prochnow A. Professional identity as perceived by nursing students: from professional activity to acknowledgement and enhancement. Rev Enferm UERJ [Internet]. 2014 [cited 2018 June 03]; 22(2):200-5. Available from: http://www.epublicacoes.uerj.br/index.php/enfermagemuerj/ article/view/13587/10397

2. Oliveira GJN, Germano RM, Valença CN, Cossi MS, Câmara AG, Pinto DPSR. Fatores relacionados à identidade profissional do enfermeiro: Visão dos discentes. Enferm Global [Internet]. 2013 [citado 2018 jun 03]; 29:138-46. Disponível em: http:// scielo.isciii.es/pdf/eg/v12n29/pt_docencia1.pdf

3. Campos PFS, Oguisso T. Enfermagem no Brasil: formação e identidade profissional pós 1930. São Paulo: Yendis; 2013.

4. Schmidt C. Identidade do professor e do aprendiz de língua alemã: um levantamento eletrônico de alguns estudos brasileiros. Rev Expectativa [Internet]. 2014 [citado 2018 jun 12]; 13(13):13957. Disponível em: http://saber.unioeste.br/index. php/expectativa/article/viewFile/8936/7081 
5. Ferreira MA. Theory of Social Representations and contributions to the research of health care and nursing. Esc Anna Nery. 2016; 20(2):214-9. doi: http://dx.doi.org/10.5935/1414-8145.20160028

6. Oliveira BGRB. A passagem pelos espelhos: a construção da identidade profissional da enfermeira. Texto Contexto Enferm. 2006; 15(1):607.doi:http://dx.doi.org/10.1590/S010407072006000100007

7. Moscovici S. Representações sociais: investigações em psicologia social. Petrópolis: Vozes; 2011.

8. Mecone MCC, Freitas GF, Bonini BB. Nursing Training in the Brazilian Red Cross in the 1940s: a Foucaultian approach. Rev Esc Enferm USP. 2015; 49(Esp2):59-66. doi: http://dx.doi.org/10.1590/ S0080-623420150000800009

9. Avila LI, Silveira RS, Lunardi VL, Fernandes GFM, Mancia JR, Silveira JT. Implications of the visibility of professional nursing practices. Rev Gaúcha Enferm. 2013; 34(3):102-9. doi: http://dx.doi. org/10.1590/S1983-14472013000300013

10. Kristoffersen AE, Stub T, Melhus M, Broderstad AR. Prevalence and associations for use of a traditional medicine provider in the SAMINOR 1 survey: a population-based study on health and living conditions in regions with Sami and Norwegian populations. BMC Complement Altern Med. 2017; 17(1):530. doi: http://dx.doi. org/10.1186/s12906-017-2037-0

11. Majda A, Ziarko E, Zalewska-Puchała J. A consistent course of events or a series of coincidences: nursing in Poland from the 19th to the 21st century. Nurs Inq. 2015; 22(4):359-70. doi: http://dx.doi.org/10.1111/nin.12110

12. Fertonani HP, Pires DEP, Biff D, Schrer MDA. The health care model: concepts and challenges for primary health care in Brazil. Cienc Saúde Coletiva. 2015; 20(6):1869-78. doi: http://dx.doi. org/10.1590/1413-81232015206.13272014
13. Silva PFA, Baptista TWF. Os sentidos e disputas na construção da Política Nacional de Promoção da Saúde. Physis. 2015; 24(2):441-65. doi: http:// dx.doi.org/10.1590/S0103-73312014000200007

14. Pinto ICM, Esperidião MA, Silva VI, Soares CM, Santos L, Fagundes TLQ et al. Trabalho e educação em saúde no Brasil: tendências da produção científica entre 1990-2010. Cienc Saúde Coletiva. 2013; 18(6):1525-34. doi: http://dx.doi. org/10.1590/S1413-81232013000600002

15. Malta DC, Morais Neto OL, Silva MMA, Rocha D, Castro AM, Reis AAC, et al. National Health Promotion Policy (PNPS): chapters of a journey still under construction. Cienc Saúde Coletiva. 2016; 21(6):1683-94. doi: http://dx.doi. org/10.1590/1413-81232015216.07572016

16. Vendruscolo C, Ferraz F, Prado ML, Kleba ME, Reibnitz KS. Teaching-service integration and its interface in the context of reorienting health education. Interface. 2016; 20(59):1015-25. doi: http://dx.doi.org/10.1590/1807-57622015.0768

17. Santos JLG, Pestana AL, Guerrero P, Meirelles PSH, Erdmann AL. Práticas de enfermeiros na gerência do cuidado em enfermagem e saúde: revisão integrativa. Rev Bras Enferm. 2013; 66(2):25763.doi:http://dx.doi.org/10.1590/S003471672013000200016

18. Urbanetto JS, Magalhaes MCC, Maciel VO, Sant'Anna VM, Gustavo AS, Poli-de-Figueiredo CE. Work-related stress according to the demandcontrol model and minor psychic disorders in nursing workers. Rev Esc Enferm USP. 2013; 47(5):1180-6. doi: http://dx.doi.org/10.1590/ S0080-623420130000500024 